\title{
EFFECT OF TEMPORARY CALF REMOVAL NUMBERS IN TIMED ARTIFICIAL INSEMINATION PROTOCOLS ON WEANING WEIGHT FROM NELORE CALVES
}

\author{
Luisa Cunha Carneiro ${ }^{1}$, Carla Crisitan Campos$^{2}$, Ricarda Maria Santos² \\ 1 UNESP - Campus Júlio Mesquita Filho \\ 2 UFU \\ Correspondência: Luisa Cunha Carneiro: luisacunhacarneiro@hotmail.com
}

\begin{abstract}
This study was conducted to evaluate the effect on the weaning weight of Nelore calves from two factors: the number of times the calves were temporarily removed from their mothers during a timed artificial insemination (TAI), and the month of birth. Attention was given to any possible interaction between these factors. Suckled beef Nelore cows $(n=271)$ with more than 30 days postpartum were synchronized to a TAl protocol as follows: Day 0: insertion of intravaginal progesterone device $+2.0 \mathrm{mg}$ of estradiol benzoate; Day 7: application of $12.5 \mathrm{mg}$ of dinoprost tromethamine; Day 9: removal of progesterone device $+1.0 \mathrm{mg}$ of estradiol cypionate + temporary calf removal (TCR); Day 11: TAI + return of the calves to cows. The calves whose mothers conceived after the first insemination were subjected to TCR once, those found empty after 30 days were resynchronized and inseminated according to the TAI protocol and thus, their calves were subjected to TCR a second time. The weaning weight was adjusted to 210 days. Statistical variance analysis was performed by SAS statistics program. It was observed that there was no effect from the number of removals on the weaning weight $(P>0.05)$; on the other hand, the month of birth did affect it $(P<0.05)$. In conclusion, the number of TCR's for TAl protocols during the breeding season did not impact the weaning weight of the calves. However, the month of birth did affect the weaning weight of beef calves, since those born at the beginning of the birth season were heavier.
\end{abstract}

Key words: beef cows; reproduction, reproductive management; synchronization

\section{EFEITO DO NÚMERO DE REMOÇÕES TEMPORÁRIAS EM PROTOCOLOS DE INSEMINAÇÃO ARTIFICIAL EM TEMPO FIXO NO PESO A DESMAMA DE BEZERROS NELORE}

RESUMO: Objetivou-se avaliar os efeitos causados pelo número de remoções temporárias de bezerros (RTB) Nelore durante o protocolo de inseminação artificial em tempo fixo (IATF) no peso a desmama, além do efeito do mês de nascimento e da interação entre eles. Vacas de raça Nelore ( $n$ = 271) com mais de 30 dias pós-parto foram sincronizadas com o seguinte protocolo de IATF: Dia 0: inserção de dispositivo intravaginal de progesterona $+2,0 \mathrm{mg}$ de benzoato de estradiol; Dia 7: aplicação de 12,5 mg de dinoprost-trometamina; Dia 9: remoção do dispositivo de progesterona $+1,0$ mg de cipionato de estradiol + RTB; Dia 11: IATF + retorno dos bezerros as vacas. Os bezerros cujas mães emprenharam após a primeira IATF foram submetidos à RTB apenas uma vez, já aquelas encontradas vazias após 30 dias foram ressincronizadas e seus bezerros foram submetidos à RTB pela segunda vez. O peso a desmama foi ajustado para 210 dias. A análise de estatística foi realizada pelo programa SAS. Não houve efeito do número de remoções temporárias no peso ao desmame $(P>0,05)$, porém, o mês de nascimento afetou esta variável $(P<0,05)$. Concluiu-se que, o número de RTB em protocolos de IATF durante a estação de monta não afetou o peso a desmama dos bezerros. No entanto, o mês de nascimento afetou o peso a desmama de bezerros de corte, uma vez que aqueles que nasceram no início da estação de nascimento foram mais pesados.

Palavras-chave: manejo reprodutivo; reprodução; sincronização; vacas de corte 

weaning weight from Nelore calves

\section{INTRODUCTION}

The practice of controlled feeding managements or temporary calf removal (TCR) works as a strategy to induce cyclicity, since it increases the frequency of luteinizing hormone (LH) pulses, stimulating follicular development and ovulation induced by the $\mathrm{LH}$ peak in cows with more than 30 days postpartum (Yavas and Walton, 2000).

The TCR management consists of separating the calf from the cow for a period of 48 to 72 hours. It is an easy and cost-effective technique but can be labor intensive (Silveira et al., 2010). According to Pires et al., (2004), a reproductive response obtained with TCR management depends on the age of the cow and calf, the nutritional status or even the herd genotype. It is important to note that some breeds respond better to TCR than others.

An alternative to TCR is the use of equine chorionic gonadotropin (eCG) during the timed artificial insemination (TAl) protocol. This hormone, when administered to anestrus cows, creates conditions to stimulate follicular growth and ovulation, even in cows that have impaired release of gonadotropins. Although it's high cost limits its use (Baruselli et al., 2008).

The adoption of TCR or the use of eCG will depend on the type of the farm, the management at the farm, the number of workers at the farm, and others factors. The use of eCG justified by removal of the cows abolishes the day of withdrawal of the progesterone (P4) implant, thus increasing the cost of the protocol (Silveira et al., 2010).

According to Oliveira et al. (2006), the most efficient cows tend to give birth earlier during the birth season and wean their calves heavier since they have more forage of good quality and for a longer period, that's why it is important to evaluate the interaction of the weaning weight at the time of the birth.
So, based on all this information, this study was conducted to evaluate the effects of month of birth and the number of TCR for TAl protocols on weaning weight adjusted to 210 days of age.

\section{MATERIAL AND METHODS}

This study was conducted to the Ethics Committee on Use and care of Animals in accordance with the ethical use of animals for experimentation of the Faculty of Veterinary Medicine, Federal University of Uberlandia and the experimental was approved for implementation by all proposed conditions of work.

The study included 271 Nelore female cows, with more than 30 days postpartum. The cows were kept in Brachiaria decumbens pasture with ad libitum access to water and mineral supplement. The animals selected for the study were free from any anatomical and reproductive disorders and were not suffering from any health problems. The animal calendar health was followed regularly for the entire herd according to the State law for beef cattle.

The body condition score (BCS) of the animals were evaluated at the beginning of the TAI protocols according to a scale of one to five adjusted to 0.25 (Edmonson et al., 1989). Animals with a BCS $\geq 2.50$ were included in the experiment.

Animals with a BCS above 2.50 were treated with a synchronization protocol as follows: Day 0 - insertion of an intravaginal P4 device (CIDR®, Pfizer Animal Heatlth, Sao Paulo, Brazil) +2.0 $\mathrm{mL}$ intramuscular (IM) of estradiol benzoate (Estrogin $\AA$; Farmavet, Sao Paulo, SP, Brazil); Day 7- $2.5 \mathrm{~mL}$ of dinoprost trometamine, IM (Lutalyse®; Pfizer Animal Health, Sao Paulo, SP, Brazil); Day 9 - withdrawal of the P4 device $+0.5 \mathrm{~mL}$ injection of estradiol cypionate IM $(E C P \AA$, Pfizer Animal Hearth, Sao Paulo, SP, Brazil) + calf 
removal, Day 11 - TAl + return of calves with the cows) (Figure 1).

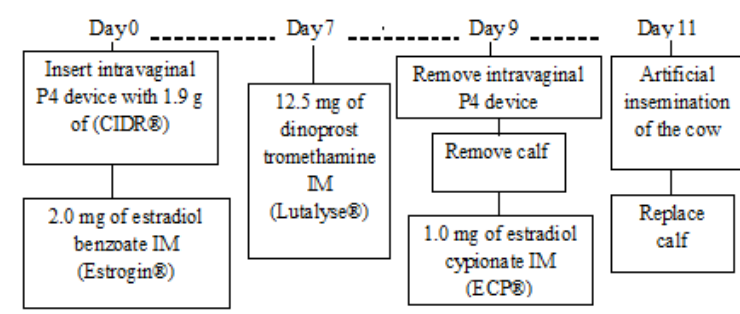

Figure 1 - Schematic representation of timed artificial insemination protocol. Source: Adapted from Meneghetti et al. (2006).

Cows with more than 30 days postpartum were examined by ultrasound (7.5 MHz linear transducer) and classified by the presence or absence of corpus luteum before the start of the protocol.

Doses of semen from Nelore bulls were subjected to a prior assessment and used for each breeding season.

The cows were divided into two groups. Group 1: animals $(n=190)$ were subjected to the TAl protocol, became pregnant with one insemination in fixed time, and had their calves temporarily removed only once. Gorup 2: those animals $(n=81)$ that failed to conceive after the first insemination, therefore, they were re-synchronized and had their calves temporarily removed a second time for TAI protocol.

The breeding season was between December 2010 and February 2011. Thirty days after insemination, the pregnancy diagnosis was made by ultrasound. Those cows found empty were re-synchronized, and those which returned to estrus before pregnancy diagnosis were re-inseminated conventionally 12 hours after heat detection.

The birth season of the calves was between September and December 2010. The suckling period lasted until the calves were seven months old, so weaning occurred between April 2011 through July 2011. During the weaning period, the calves were weighed on an electronic scale (LD2000E®). The weaning weight was adjusted to 210 days of age.

The effects of the number of temporary removals and month of birth, and the interactions between these two factors on weaning weight adjusted to 210 days were analyzed by variance analysis in SAS statistics program. For this study, differences were considered significant when $\mathrm{P}<0.05$.

\section{RESULTS}

In this study, no significant effect was observed from the number of temporary removals $(P>0.05)$ during the TAl protocol. Also there was no interaction effect between the number of removals and month of birth $(P>0.05)$. However, the month of birth did affect the weaning weight of calves at 210 days of age $(P<0.05)$.

The present study showed that the number of TCR did not affect the growth of the calves $(P>0.05)$. The short period of the temporary removal did not interfere with weaning weight (Table 1).

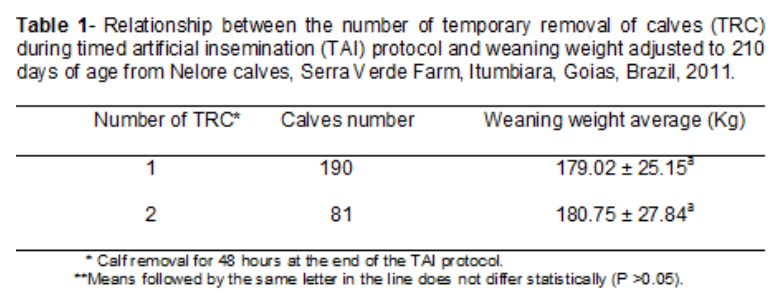

At the end of the TCR it is important to note that rejections by the mothers can occur in some animals, although, in the present study, no calf was rejected by its mother.

The weaning weight of the calves was affected by the month of birth (Table 2). The calves born in the beginning of the birth season where heavier when compared to those born at the end of the birth season. 

weaning weight from Nelore calves

Table 2 - Relationship between month of birth and weaning weight adjusted to 210 days of age from Nelore calves, Serra V erde Farm, Itumbiara, Goias, Brazil, 2011

$\begin{array}{lcc}\text { Month of birth } & \text { Calves number } & \text { Weaning weight average }(\mathrm{Kg}) \\ \text { September } & 48 & 186.15 \pm 27.47^{\mathrm{a}} \\ \text { October } & 78 & 182.68 \pm 27.04^{3.0} \\ \text { November } & 77 & 177.66 \pm 24.65^{0.0} \\ \text { December } & 68 & 173.40 \pm 23.84^{\circ}\end{array}$

-Means followed by the different letters in the line differ statistically $(P<0.05)$.

Those calves $(n=48)$ born in the beginning of the birth season, specifically in September, were heavier than those born in November $(n=77)$, and December $(\mathrm{n}=68)$, as table 2 shows $(\mathrm{P}<0.05)$.

The calves born in October $(n=78)$, weighed more than those born in December $(n=68 ; P<0.05)$. Yet, it was evident that those born in November $(n=77)$ had the lowest birth weight when compared to those born on September $(n=48)$ and October $(n=78 ; P<0.05)$.

So it is clear to show that, in this study the month of birth was considerable to affect the weaning weight of calves adjusted to 210 days of age $(P<0.05)$.

\section{DISCUSSION}

The studies that concern TCR mostly evaluate the results on the conception rate of cows without, however, evaluating the influence of TCR on the growth and further development of the calves. To remedy this lack of data this study assessed the calves development, showing that the short period of calf removal did not affect the weaning weight of them.

In accordance with this study, Ernandes et al. (2009) evaluated the weaning weight adjusted to 205 days in Nelore and crossbred Nelore/Red Angus calves subjected to a 48 hours temporary removal. They concluded that the 48 hours of temporary removal did not affect the weaning weight of the calves when compared to the control group, except in those females Nelore calves that had a lower weight when compared to the control group.

To implement a program of TCR at beef cattle, it is necessary to have sufficient infrastructure capable of assuring the safe and efficient containment of the animals. This will avoid injury to animals, damage to fences and pens, and others things.

Bocchi et al. (2004), in a study with Nelore calves in four regions of Brazil, demonstrated that for all regions, the weaning weight of the calves were heavier in those born during the winter (July-September) and spring (OctoberDecember), with higher values observed during September and October months.

Although, the lowest weaning weight of the calves was from those born in summer (January to March). Their findings are similar to those found in this experiment, where higher weaning weight was observed in calves born between September and October.

According to Dal-Farra et al. (2002), cows achieve higher milk production when there is more pasture of good quality available, and in Brazil, this happens between September and October months, so, this could be an explanation of the high weaning weight of those calves born between September and October, since there is a strong interrelationship between growing period and feeding moment that reach the calves to have higher rates of growth during the nursing period under these ideal conditions.

It is interest to know that in most of the studies that evaluate the effects of weaning weight when compared to others variables, the most important effects might been caused by different weather, pasture conditions and management.

In this study, the month of birth did affect the weaning weight of the calves $(P<0.05)$. This is due to the fact that calves born near the beginning of the birth season (September 2010) 
suffered less from adverse environmental conditions than those born at the end of the birth season when the incidences of diseases such as diarrhea and pneumonia is smaller, and the lack of rain has not adversely affects the feeding of colostrum and healing of the navel.

The results found in this study are different from those reported by Bolcskey (1987), who found that the weaning performance in calves born in August and September was lower than in those calves born between February and April.

In an experiment conducted by Kova'cs et al. (1994), they found that the weight of calves born the autumn season was the highest, which is not in accordance with this study, where the highest weight of calves was during the fall season. These contradictory findings for the effect of season are certainly due to difference in surroundings and management practice.

Szabó et al. (2006) compared the effect of breed, age of dam, calving year, calving season and sex of calves on a 205-day adjusted weaning weight. They conclude that those calves born in summer reached the highest weaning weight (203kg), while the lowest was from those calves born in winter period (183kg).

In two experiments conducted by Waterman et al. (2012), they found that cows with calves removed at the time of early weaning (permanent calf removal) produced calves that were $2 \mathrm{~kg}$ heavier $(P<0.01)$ when compared to cows that had their calves removed at a normal weaning (calves suckled cows until normal weaning approximately $210-\mathrm{d}$ of age).

According to Robinson et al. (1999)., the imposed early weaning treatment allowed nutrients used to support lactation to be repartitioned towards maternal tissues, such as reproduction, in the nursing cows, and consequently benefit endocrine mechanisms that influence uptake and utilization of nutrients by the conceptus.

When some producers do some weaning strategies, but they don't find good results in weaning weight, probably the nutritional environment (i.e., forage quality) at the moment of this practice may be inadequate to meet all requirements that are necessary for the cows and calves.

The effect of season of birth, in the specific surroundings of Brazil, is somewhat different from previous studies. This result demonstrated the importance of management practice and weather conditions.

\section{CONCLUSION}

In conclusion, the number of temporary calf removal for timed artificial insemination protocols during the breeding season did not impact the weaning weight of the calves. However, the month of birth did affect the weaning weight of beef calves, since those born at the beginning of the birth season were heavier.

\section{REFERENCES}

BARUSELLI, P.S.; JACOMINI, J.O.; SALES, J.N.S. et al. Importância do emprego da eCG em protocolos de sincronização para IA, TE e SOV em tempo fixo. In: $3^{\circ}$ SIMPÓSIO INTERNACIONAL DE REPRODUÇÃO ANIMAL APLICADA. Londrina, 2008. Anais. Londrina, 2008. p.146.

BOCCHI ,A.L.; TEIXEIRA, R.A.;

ALBURQUERQUE, L.C. Idade da vaca e mês de nascimento sobre o peso ao desmame de bezerros nelore nas diferentes regiões brasileiras. Acta Scientiarium Animal Sciences, v.26, n.4, p.475-482, 2004.

BOLCSKEY, K. A. borjúnevelõ képesség változása az elések számának fuggvényében. Állattenyésztés és Takarmányozás, v.36, n.4, p.305-311,1987.

DAL-FARRA, R.A.; ROSO, V.M.; SCHENKEL, F.S. Efeitos de ambiente e de heterose sobre o 

weaning weight from Nelore calves

ganho de peso do nascimento ao desmame e sobre os escores visuais ao desmame de Bovinos de Corte. Revista Brasileira de Zootecnia, v.31, n.3, p.1350-1361, 2002.

EDMONSON, A.J.; LEAN, I.J.; WEAVER, L.D. et al. A body condition scoring chart for Holstein dairy cows. Journal of Dairy Science, v.72, n.1, p.68-78, 1989.

ERNANDES, L. K.; CARLOS, J.B.; BRUNO A. et al. Avaliação do ganho de peso ajustado para 205 dias em bezerros da raça Nelore e mestiços Nelore x Red Angus, submetidos ao desmame Temporário. Revista Acadêmica Ciências Agrárias Ambientais, v.7, n.4, p.407-413, 2009.

KOVÁCS, A.; SZFCS, E.; BORI, T. et al. A szu letési hónap és az ivar hatása a limousin borjak választási, valamint éveskori teljesítményére.

Állattenyésztés és Takarmányozás, v.43, n.3, p.209-21, 1994.

MENEGHETTI, M.; LOSI, T.C.; VILELA, E.R. et al. Cipionato ou benzoato de estradiol associado a inserção do dispositivo intravaginal de progesterona na resposta a protocolo de inseminação artificial em tempo fixo. Acta Scientiae Veterinariae, v.34, Supl.1, p.1-7, 2006.

OLIVEIRA, R. L.; BARBOSA, M.A.A.F.; LADEIRA, M.M. Nutrição e manejo de bovinos de corte na fase de cria. Revista Brasileira de Saúde e Produção Animal, v.7, n.1, p.57-86, 2006.

PIRES, V.A.; ARAUJO, C.R.; MENDES, Q.C. Fatores que interferem na eficiência reprodutiva de bovinos de corte. In: 5 SIMPÓSIO SOBRE PECUÁRIA INTENSIVA NOS TRÓPICOS, Piracicaba, 2004. Anais. Piracicaba. 2004. p.355-398.

ROBINSON, J.J.; SINCLAIR, K.D.; MCEVOY, T.G. Nutritional effects on fetal growth. Animal Science, v.68, n.2, p.315-331, 1999.

SILVEIRA, A.P.; COSTA, M.Z.; FILHO, R. et al. Efeito do período pós-parto sobre a taxa de prenhez de vacas de corte submetidas à IATF (inseminação artificial em tempo fixo).

Colloquium Agrariae, v.6, n.2, p.40-45, 2010.

SZABÓ, F.; NAGY, L.; DÁKAY, I. et al. Effects of breed, age of dam, birth year, birth season and sex on weaning weight of beef calves.

Livestock Science, v.103, p.181-185, 2006.

WATERMAN, R.C.; GEARY, T.W.; PATERSON, J.A. et al. Early weaning in Northern Great plains beef cattle production systems: In. Performance and reproductive response in range beef cows. Livestock Science, v.148, p.26-35, 2012.
YAVAS, Y.; WALTON, J.S. Induction of ovulation in postpartum suckled beef cows: a review.

Theriogenology, v.54, n.1, p.1-23, 2000. 